How to cite this article:

Soyemi, K. A., Olufemi, O. A., \& Adeyemi, S. B. (2020). External audit(or) quality and accrual earnings management: Further evidence from Nigeria. Malaysian Management Journal, Vol. 24(July), 31-56. https://doi.org/10.32890/mmj.24.2020.10322

\title{
EXTERNAL AUDIT(OR) QUALITY AND ACCRUAL EARNINGS MANAGEMENT: FURTHER EVIDENCE FROM NIGERIA
}

\author{
*KENNY ADEDAPO SOYEMI \\ OLUBUKONLA ABOSEDE OLUFEMI
}

Department of Accounting

Faculty of Administration \& Management Sciences

Olabisi Onabanjo University, Ago-Iwoye, Nigeria

\author{
SEMIU BABATUNDE ADEYEMI \\ Department of Accounting \\ Faculty of Management Sciences \\ University of Lagos, Akoka, Nigeria
}

*Corresponding author: k.ade.soyemi@gmail.com

\begin{abstract}
Hinged on the quest for quality financial information, this study examined the influence of audit quality on restricting the incidence of accrual-based earnings management among 30 quoted non-financial firms in Nigeria, an emerging country which provides a rich institutional background and cultural setting different from developed nations. Secondary data were gathered from annual reports and audited financial statements for 11 years from 2008-2018. These firms were selected using stratified sampling technique. Thereafter, panel ordinary least square technique was used to estimate specified model for the study. While the descriptive statistics revealed the absence of accrualbased manipulation of earnings among quoted non-financial firms in Nigeria, the multivariate fixed effects ordinary least square depicted that audit quality variables adopted are mutually and statistically significant in explaining 49 percent changes in earnings management. Further, audit tenure and auditor
\end{abstract}


independence exhibited positive and significant relationship, while total assets as the control variable, displayed a negative and significant influence on earnings management. Surprisingly, the size of audit firm appeared positive but statistically insignificant. Consequently, the relevant authorities and policy makers should not only sustain but improve on the current practice of audit engagement partner and/or auditor switch after certain years of continuous engagement to enhance their independence and reduce client-auditor engagement periods to avoid familiarity threat.

Keywords: Audit fees, auditor independence, auditor tenure, discretionary accruals, Nigeria.

JEL Classification Codes: M41, M42

Received: 14/6/2020 Revised: 16/7/2020 Accepted: 21/7/2020 Published: 30/8/2020

\section{Introduction}

Among the many concepts in the accounting literature which have refused to quit the scene of research studies, and may not leave soon, earnings management is predominant. According to Yasser and Soliman (2018), earnings management is defined as "a purposeful intervention in the external financial reporting process, with the intent of obtaining some private gain" (p. 217). It assumed an alarming rate, throwing up a renewed interest in particular, following the financial crisis that rocked major and blue-chip entities like Enron, WorldCom, Pharmalat. There are renewed cases, such as Carillion and BHS in the United Kingdom (UK), IL \& FS and Satyam Computer Services in India. In Nigeria, the Cadbury and Lever Brothers' cases also come handy. Similarly, in 2010, the AAE Professional Services were indicted for non-compliance with statements of accounting standards during the audit of Alliance General Insurance Ltd/Alliance Life Assurance Plc by the Financial Reporting Council of Nigeria (FRCN). In the same vein, the accounts of Stanbic-IBTC for the year ended December 31, 2013 and 2014 were once withdrawn owing to infractions by the FRCN while the Securities and Exchange Commission (SEC) had reasons to investigate the activities of Oando Plc. These incidences of earnings manipulation in emerging country like Nigeria provide excellent research motivation as to its existence and how it can be restricted, or at best, contained to barest minimum. These trends are worrisome, especially at they relates to the international professional practice of Big4 audit firms, dotted as custodian of excellent audit practice. This notion appears to be eroding. Consequently, this may be asymptomatic of yet another imminent global corporate failure which may be put at the door step 
of managers' opportunistic behaviour in manipulating reported earnings. The liberty with which managers and those charged with the governance of entities, in particular the corporate sectors who manipulate items of revenue and income in the financials is not only alarming, but unprecedented. This is simply a dishonest financial reporting. Principally, managers manipulate earnings for private gains. This is noticeable in the definition by Yasser and Soliman (2018) and cited earlier. Examples are deliberate understatement or overstatement of expenses in order to boost profits and be rewarded based on the fictitious profit or report losses in order to pay less taxes, respectively. Other reasons relate to the management's opportunistic tendencies to manipulate earnings including avoiding reporting losses (Charoenwong \& Jiraporn, 2009); meeting targeted EPS (Jordan, Clark \& Hames, 2010) and decreasing income volatility (Hijazi \& Al-Thuneibat, 2015).

These preponderance of scandals have resulted in the mandate for higher audit quality as a key strategy, to checkmate the occurrence of earnings management. This is premised on previous empirical studies such as Sitanggang, Karbhari, Matemilola and Ariff (2019), Lopes (2018), Akintayo and Salman, (2018), Azibi, Azibi and Tondeur (2017), Alzoubi (2016), Nawaiseh (2016), Aliyu, Musa and Zachariah (2015) and Jordan, Clark and Hames (2010). Audit is an assurance engagement activity, which lends credibility to financial reports, prepared by management to render stewardship to owners of businesses. Consequent upon agency problem, rooted in contracting theory, between shareholders and managers, external auditors are appointed and engaged to detect material misstatements, thereby eliminating or at best minimising agency cost such as the earnings management. As provided in the International Standard on Auditing (ISA) No. 240,, 'The Auditor's Responsibility to Consider Fraud in an Audit of Financial Statements' issued by the International Auditing and Assurance Standards Board (IAASB) of the International Federation of Accountants (IFAC), it is the primary responsibility of the management or those charged with the governance of the entity to ensure prevention and detection of fraud. This is usually done through establishment and maintenance of excellent internal controls. Further, external auditors are as well saddled with the onerous task of planning and conducting the audit engagement in a bid to reducing audit risk to the barest minimum in the light of given circumstances. Audit risk connotes an inappropriate audit opinion which is usually contained in the final audit report. A material misstatement may be unintentional (error) or otherwise (fraud). Both are within the purview of the auditor to prevent and ultimately detect, if contained in financial statements. The risk of the latter is also specifically provided for in ISA 240, hence the auditor is urged to design, identify and assess the occurrence of such risk before (especially at the planning stage), during and after the field-work prior to signing the audit 
report. Expectedly, auditors are to act with due care and utmost skills during their engagements, hence providing excellent audit quality which ultimately is transmitted into the financial reporting process and increases the level of quality of financial reports. According to Knechel (2016, p. 216), the audit quality is described as the twin-possibility for external auditors to detect a misnomer or an aberration during audit engagements and as well report such (if not corrected by clients) in his report. While the former is known as proficiency, the latter is objectivity. Clearly, the audit quality is desirable to achieve quality financial information.

The Nigerian context provides a rich contextual background in studying the influence of audit quality on earnings management. Besides a few examples of incidence of accounting manipulations, the paucity of scholarly studies in this area is another justification. The few that are available are conducted along sectoral dimensions, for example, Mohammed \& Abibakar, 2018; Akintayo \& Salman, 2018 and Olabisi, Agbatoogun \& Akinrinlola, 2017 were conducted in the banking industry; Alao \& Gbolagade, 2019 and Tyokoso and Tsegba (2015) were within the oil and gas industry. The continued dominance by Big4 audit firms in the Nigerian audit market alongside weak nature of her corporate governance mechanism coupled with little or no litigation risk against auditors are other motivations for this study. Against these backdrops and the specific need to investigate whether the universality of quality of audit is correct as claimed overtly by United States of American market (Chen, Chen, Lobo \& Wang, 2011), this study sought to examine the influence of audit quality on accrual earnings management among quoted non-financial firms in Nigeria. Therefore, the findings from this study is of immense benefits to relevant authorities, such as the Financial Reporting Council of Nigeria (FRCN), the Institute of Chartered Accountants of Nigeria (ICAN), the Securities and Exchange Commission (SEC) and the Nigerian Stock Exchange (NSE) among others in drawing up regulations to improve and further strengthen the audit quality in particular, and the accounting profession in general. Given the introduction, this paper thus proceeds as follows; the second section discusses previous related empirical studies alongside the theoretical review. Meanwhile the methodology and empirical results are presented in third and fourth sections respectively and the conclusion.

\section{Literature Review}

\section{Earnings Management}

Yasser and Soliman (2018, p. 217) viewed earnings management as the deliberate and or intentional behaviour of management to intervene in 
financial reporting processes for private gain. This opportunistic behaviour of managers contradict their fiduciary position as entrenched in the laws and regulations guiding their appointments. While commenting on the broad nature of earnings management, Alzoubi (2016) likened the concept known as earnings management to a composite concept whose elements are composed of a whole range of managers' ineptitude nature to use estimates and judgements in arriving at the value(s) in the accounts. Further, Healy \& Wahlen (1999) cited in Abbadi, Hijazi and Al-rahahleh (2016) provided an encompassing definition of earnings management:

"Earnings management occurs when managers use judgment in financial reporting and in structuring transactions to alter financial reports to either mislead some stakeholders about the underlying economic performance of the company or to influence contractual outcomes that depend on reported accounting numbers". (p. 56).

The above definition is not only apt, but clearly indicates that management enjoys using their discretions. Such discretions may be used for and against the shareholders and other stakeholders but to the former's benefits. In the course of preparing the accounts, the management makes judgments alongside estimates based on experience and information available to them. During this phase, the managers exhibit opportunistic behaviour on earnings using various methods and techniques. One way is accrual based earnings management. This connotes exercising discretion by making favourable judgements on choice(s) of accounting estimates. Manipulation of real transactions is another technique. According to Zgarni, Hlioui \& Zehri (2012), the latter involves actual alteration of operating activities and decisions such as over-production, offering discounts to increase sales volume and others. However, the trio opine that accrual based manipulation is more risky and easily detectable by auditors; hence, the prevalent of real earnings among entities.

\section{Audit Quality}

Knechel (2016, p. 216), defined the audit quality as the twin-possibility for external auditors to detect a misnomer or an aberration during audit engagements and as well report such (if not corrected by clients) in his report. While the ability of auditors to discover material misstatements is known as auditor expertise (also called auditor competence), auditor independence is used to describe the fearlessness for auditors to report such misstatements, through a qualified, disclaimer or adverse opinions, if not corrected. These two attributes of auditors are combined to produce the composite concept of 
auditor quality. The auditors are seen and taken as the principal determinant of audit quality; hence, the rigorous nature of processes and procedures involved before being certified as practicing auditors. Further, Knechel (2016) cautioned the need to treat both attributes as dependent, rather than separate and independent or mutually exclusive construct. These traits are also combined to produce four possibilities with regard to the levels of audit quality, at least, in the non-regulated environment. These are (a) low auditor independence and auditor competence, (b) high auditor independence and auditor competence, (c) high auditor independence and low auditor competence, and (d) the low auditor independence and high auditor competence. He maintained that none of these are desirable, as they tend to destroy the accounting profession, hence there is the need for a re-defined regulation of audit quality to reflect the uniqueness of audit. While noting the unobservable nature of audit quality, previous studies have adopted different proxies in measuring the concept. Prominent measures are audit fees (Miko \& Kamardin, 2015); auditor size (Alzoubi, 2016; Miko \& Kamardin, 2015); auditor tenure (Nawaiseh, 2016; Miko \& Kamardin, 2015). While these are treated as determinants of audit quality in audit literature, the conclusion is that they are measures of either dimensions of auditor independence or competence.

\section{Empirical Review: Evidence from Developed Nations}

There are copious studies regarding audit quality and earnings management among developed nations. This appears to have slowed down recently. A few recent ones are reviewed hereinafter. Commencing with the study by Sitanggang et al. (2019) conducted among large manufacturing companies in United Kingdom for four years, between 2010 and 2013 using abnormal of operating cash flow abnormal production cost and real earning management index as proxies for earnings management. Hinged on the estimates as reported in the panel fixed effects, audit fees displayed negative and significant influence on abnormal operating cash flow, while it maintains a rather positive and significant association with abnormal production cost and real earnings management index. It provides evidence of limited association between audit quality and actual manipulation of reported earnings, maintaining the need for managers of entities to curb by themselves deliberate manipulations of earnings, rather than engaging any Big4 firms to assist which may lead to an erosion of the company's value. Further, using UK listed sampled companies across all sectors (excluding financial sector), El Guindy \& Basuony (2018) also explored the impact of auditor tenure on earnings management alongside a dual objective of whether such relationship was moderated by similar accounting standards, as according to them, UK firms are allowed to report using UK-GAAPs or International Financial 
Reporting Standards (IFRS). The empirical analysis from this study shows negative and significant relationship between auditor tenure and incidence of discretionary accruals which is expected and consistent with prior studies. In addition, this trend is consistent irrespective of the accounting standard under which UK firms present their reports.

Lopes (2018) examined this relationship among 4,723 sampled non quoted firms in Portugal for a time dimension of three years (2013-2015). The findings arising from this study provide strong evidence as to the influence of audit quality on earnings management, explaining 24.3 percent (adjusted $\mathrm{R}^{2}$ ) of changes in behaviour of discretionary accruals. The audit firms' size, one of the audit quality indicators, proxied with the usual Big4 versus nonBig4 binary variables, which appear significant and negative, indicates a reduction in earnings manipulations as firms switch from the non-Big4 to Big4 professional accounting firms. The Big4 accounting firms constrain management tendencies to manipulate earnings. Further, Azibi, Azibi and Tondeur (2017) examined the influence of audit quality, proxied with auditor selection between Big4 and non-Big4, alongside institutional activism on the incidence of earnings management within the French context, pre- and post-Enron debacle. Adopting Kothari, et al.'s (2005) model, 188 French enterprises listed on SBF250 index were used as the sample, for six years from 2000 to 2007. Overall, the findings reveal the movement of adjusted $R^{2}$ from 2.92 percent (10.58\% for mean of three-year estimation, 2000-2002) variations in the pre-enron era to 3.91 percent $(11.44 \%$ for mean of four-year estimation, 2003-2006) variations in the earnings management as explained by the auditor choice and institutional activism. There were no significant differences in the magnitude of discretionary accruals reported by either Big4 or non-Big4 firms.

Similarly, Molik, Mir, Mclver and Bepari (2013) provided empirical evidence of Australian firms' uncanny attitude to manipulate earnings, especially during the global financial crisis and show to what extent audit quality, proxied with Big4/non-Big4 dichotomy has constrained this behaviour. While adopting Jones and modified Jones models to estimate abnormal accrual among 149 unbalanced panel firms, for a period of 4 years, spanning 2006 to 2009, it was discovered that Australian firms embarked on income decreasing earning manipulation strategies during the global financial crisis. Unfortunately, this was not sanctioned by Big4 firms, implying insignificant influence of audit quality on discretionary accruals. Further, Chi, Lisic and Pevzner (2011) provide plausible answers to pertinent question as to whether enhanced audit quality discourages entities from manipulating accruals, that is, accruals earnings management, rather encourages real manipulation of transactions. Consequently, the trio examine the effects of audit quality on 
real earnings management. In addition to confirming the inverse relationship between audit quality and accruals manipulation, it also found that the expected outcome of managers switching to real manipulation of earnings in the presence of enhanced audit quality, proxied primarily with Big4/nonBig4 professional firms and auditor tenure.

\section{Evidence from Developing Nations}

Studies from developing and/or emerging countries largely reflect those of developed countries, especially in terms of methodology and findings. In the Egyptian context, Yasser and Soliman (2018) examined the effect of audit quality on earnings management among top 70 EGX100 listed firms for five years from 2011 to 2016 . Like most studies, the study adopts the modified Jones' model in computing the absolute value for abnormal accruals. Thereafter, multiple Ordinary Least Square (OLS) was adopted as the estimation technique. Overall, 8.4 percent of variations in earnings management were explained by measures of audit quality, including Big4, industry specialisation, auditor tenure, client size with leverage and operating cash flows as control variables. Of these, audit tenure and client size seem significant and also show the expected sign of positive and negative respectively. This connotes that the longer the auditor-client relationship, the greater the incidence of earnings manipulations by management.

Almarayeh et al. (2020) consolidated past studies in Jordan by a renewed investigation into the association between two auditor characteristics, namely auditor size and audit fees as well as earnings management. With a final 251 firms/year observations, similar to past Jordanian studies, over a 5 -year period, the results depict no significant influence of these two proxies of audit quality and restriction on earnings manipulations in Jordan. Further, the results based upon a generalized least square regression (GLS) show a positive and significant influence of all control variables (firm size, growth and ROA), except leverage, though positive but insignificantly related to accrual earnings management. In addition, a relatively low value (18\%) was reported as the adjusted $\mathrm{R}^{2}$ indicative that the totality of the explanatory variable explain only 18 percent differences in earnings management. Similar study by Alzoubi (2016) examines the effect of disclosure quality on the magnitude of earnings management among 86 industrial companies quoted on the Amman Stock Exchange for four years between 2007 and 2010. Using a GLS regression in order to surmount the heteroskedasticity problems of OLS, the findings from the study show disclosure quality exerting a negative influence on incidence of earning management, accounting for 45 percent variations therein, thereby improving the quality of financial reporting. Of note are the audit firm size (measured by Big4 versus non-Big4 dichotomy), 
client's size (natural log of total assets) and clients' profitability (proxied with ROA). As expected, all displayed a negative and significant relationship with earnings management. Nawaiseh (2016) investigates the impact of external audit quality on earnings management among 13 listed banks for five years from 2006 to 2010. The study also lends credence to the association between audit quality and earnings management by Jordanian banks, accounting for 47.6 percent of variations thereof. Specific leading audit quality factors which turned out expected signs and also depict significant influence on discretionary accruals include audit tenure, audit fees (a measure of audit independence) and international auditing firm relationship.

In addition, the trio of Ahmad, Suhara and Ilyas (2016) provide empirical evidence on the effect of audit quality on earnings management in Indonesia. Using a 420 firm-year observations comprising 105 quoted but non-regulated manufacturing firms over 4 years, from 2010 to 2013, and based on the modified Jones model, the study support the hypothesis of inverse relationship between audit quality and earnings management. In Indonesian case, the totality of audit quality factors, comprising of Big4, auditor specialization, clients' size, leverage and operating cash flows accounted for 52 percent variations in earnings management. This is dissimilar to findings from the study of Habbash and Alghamdi (2016) conducted within the context of 337 quoted non- financial Saudi Arabian firms, using a cross-sectional variation of the Kothari model to compute absolute value for discretionary accruals. Selected audit quality factors used in this study account for 9 percent of changes in discretionary accruals, with only audit opinion being negative and significant. This was in addition to firm size and operating cash flows that were control variables.

Zuo and Guan (2014) also provide empirical evidence towards explaining the association between audit firm size and industry specialization on earnings management among 2,552 Chinese firms for 4 years spanning 2008-2011. Using the usual multiple OLS, their findings are largely consistent with recent studies, with the value for adjusted $\mathrm{R}^{2}$ being 90.75 percent. Larger chunk of changes in earnings management are being explained by audit quality factors, to include auditor size, auditor specialization and a host of 5 control variables. Zgarni, Hlioui and Zehri (2012) provide evidence from 29 Tunisian quoted firms in investigating the duo influence of audit quality and implementation of the country's new financial security law on earnings management for 11 years (2000-2010). Unlike many other studies, this study examined both manipulation of discretionary accruals and real activities inherent in sales, decrease in discretionary expenditures as well as overproduction. Using a panel OLS in estimating the model specified for the study, the results depict audit quality as being a major determinant 
of earnings management, with auditor specialization and Big4 linked with lower discretionary accruals but serve as catalyst for larger manipulations of real transactions. However, as documented, elongated tenure of auditors is not related to earnings manipulations. Initially, Al-Mousawi and AlThuneibat (2011) had added their lot on relationship between audit quality and earning management activities among Jordanian firms prior to that of Alzoubi (2016) and Nawaiseh (2016). Using simple and multiple regression as well as ANOVA for comparison, Al-Mousawi and Al-Thuneibat (2011) had earlier confirm a negative relationship between audit quality and earnings management documenting a value far lower as adjusted $\mathrm{R}^{2}$ being 0.4 percent and 0.55 percent if importance and auditor size were added, with the latter being significant and negative. Using a relatively large dataset of 3,310 Chinese firms, Chen, Chen, Lobo, and Wang (2011) had earlier investigated the effects of audit quality on the duo of earnings management and cost of capital among her state-owned enterprises and that which are not state-owned enterprises. The findings from this study disclaims the widely held belief of uniformity of audit quality and its impact in restricting earnings manipulation by managers of these enterprises, with occurrence being more prevalent among state-owned enterprises than otherwise. Further, the study reports a pseudo adjusted $\mathrm{R}^{2}$ of 28 percent, size of audit firm is however positive and significantly related to the manifestation of earnings management.

\section{Evidence from Nigeria}

There are a few studies in Nigeria which have examined audit quality and incidence of earnings management by entities, which may have caused grim consequences. However, most of these were along sectoral dimensions, with a great number conducted within the context of the banking industry using quoted deposit money banks (Mohammed \& Abibakar, 2018; Akintayo \& Salman, 2018; Olabisi, Agbatoogun \& Akinrinlola, 2017; Aliyu, Musa \& Zachariah, 2015); oil and gas industry (Alao \& Gbolagade, 2019; Tyokoso \& Tsegba, 2015), among others. Though, not covered in this study, there are stand-alone studies investigating determinants of audit quality (Soyemi, Olabisi \& Akintoye, 2017) as well as in relation to other concepts, such as internal audit attributes (Soyemi, Ashogbon \& Asaolu, 2016), corporate governance (Soyemi, 2020; Abbadi, Hijazi \& Al-Rahehleh, 2016).

Although, the trio of studies by Mohammed and Abibakar (2018), Akintayo and Salman (2018) and Olabisi, Agbatoogun and Akinrinlola (2017) are similar in many respects, there are obvious differences. Mohammed and Abibakar (2018) explores the association between related-party transactions and off-balance sheet activities on earnings quality (using residuals inherent in the provision for loan losses) using a panel data set of 40 composed of 10 listed deposit money banks over a 4-year period beginning from the 
year of International Financial Reporting Standards (IFRS) adoption, that is, 2011 to 2014. While related-party transactions display positive and significant influence, off-balance sheet item variable depict a negative but insignificant relationship with earnings quality with an adjusted coefficient of determination $\left(\mathrm{R}^{2}\right)$ of approximately $19 \%$. Expanding the scope further, Akintayo and Salman (2018) in their own study examine audit quality, as well as corporate governance, as it affects earnings management among all 15 quoted banks for 10 years, between 2006 and 2015, thereby adopting a census approach. A low incidence of earnings manipulation (mean of discretionary accruals being $14 \%$ ) was confirmed. The pooled OLS estimates was considered appropriate returning an adjusted $\mathrm{R}^{2}$ of 63 percent being total variations accounted for by audit tenure, audit fees, board independence, client size and leverage in discretionary accruals. Audit quality measures were seen to have behaved expectedly in tune with a priori expectation by being negatively (audit tenure) and positively (audit fees) significant respectively. In the case of Olabisi, Agbatoogun and Akinrinlola (2017), six quoted banks, randomly selected for 10 years, from 2005 to 2014, were used as the sample size, thereby returning 60 firm-year observations. Unlike that of Akintayo and Salman, (2018), Beaver and Engel model was adopted to estimate the abnormal accruals inherent in the loan loss provisioning. Overall, and hinging on the random effects estimates, only 10 percent of variations were accounted for by joint audit, audit tenure, auditor specialization and audit independence, with joint audit (positive and significant), auditor specialisation (negative and significant) and audit independence (positive and significant) being effective audit quality factors which constrain the incidence of earning management.

Further and chuckled by financial manipulations associated with the Nigerian oil industry, Tyokoso and Tsegba (2015) investigate the impact of audit quality on earnings management of 8 (out of a total population of 10) listed oil marketing companies, for 10 years, spanning from 2004-2013. The study adopts the common modified Jones model to estimate abnormal accruals with proxies of audit quality to include audit firm size, auditor specialization and audit tenure, with client size and CFO as control variables. They collectively contributed 14.3 percent changes in discretionary accruals with audit tenure displaying negative and significant influence, in addition to the two control variables showing positive and significant relationship, as well. In addition, Okolie (2014) offer experimental proof, as to the specific influence of auditor tenure and independence in constraining management uncanny attitude in manipulating earnings. The sample size includes 57 quoted firms for 6 years, between 2006 and 2011, that is, 342 firm year dataset. Overall, the value for adjusted $\mathrm{R}^{2}$ is 14.6 percent with both measures of audit quality being significant factors in curtailing the incidence of earnings manipulations among entities in Nigeria. 


\section{Theoretical Framework}

The agency and stakeholder theories constitute the theoretical framework upon which this study is based. It was propounded by Jensen \& Meckling (1976) cited in Hosseini and Tareq (2016) connotes managers as agents of the shareholders, who are the prima facie owners of the business. Consequently, managers who are responsible for the management of affairs of entities are better informed of the business operations, hence may be tempted to act in a manner that is incoherent with that of owners. This is agency problem, hinged upon information asymmetry between managers and shareholders. To surmount this problem, owners appoint independent external auditors to lend credibility on the stewardship report rendered by management. Closely associated with the agency theory is stakeholder theory propounded by Freeman (1984) cited in Tyokoso and Tsegba (2015). Originally coined as stakeholder theory of organization management and business ethics, it addresses morals and values in managing entities. It expands those whose interests are as well to be protected to include general public and society at large. Consequently, rather than concentrating on shareholders alone, values should also be created and shared among other stakeholders such as customers, employees, suppliers, etc.

\section{Methodology}

The data for this study were essentially gathered from financial statements of 30 quoted non-financial firms (see appendix), selected through stratified sampling technique, from a total population of 105 quoted firms covering 11 years from 2008 - 2018 (Nigerian Stock Exchange Factbook, 2018). This represents approximately $29 \%$ and translates to 330 firm-year observations (33quoted non-financial firms multiply by 11years). The sample size is considered adequate and appropriate for any parametric analytical tool, having satisfied the $n \geq 30$ threshold. Further, the small sample size is typical of developing countries, such as Nigeria, where there is a significant paucity of data for research purposes. Besides, the sample size is relatively over that which is derived while applying the following statistical formular (Al-Mousawi \& Al-Thuneibat, 2011). It is stated in Equation (1)

$$
\mathrm{n}=0.25 /\left\{(0.25 / \mathrm{N})+\left(\mathrm{A}^{2} / \mathrm{E}^{2}\right\}\right.
$$

where: $\mathrm{n}=$ sample size

$\mathrm{A}=$ error level used which is equal to $10 \%$

$\mathrm{E}=$ tabulated value for a $95 \%$ confidence interval 


\section{Measurement of Variables}

\section{Dependent Variable - Earnings Management}

The dependent variable is earnings management. The pooled cross-sectional modified Jones model (Jones, 1991; Dechow et al. 1995) cited in Tyokoso et al. (2017) was adopted to obtain a proxy for discretionary accruals. According to extant literature, modified Jones model has been adjudged as the most authoritative model of estimating discretionary accruals, hence its common usage among varying studies such as Lopes (2018) and Alzoubi (2016). Overall, discretionary accruals are derived from deducting non-discretionary accruals from total accruals; hence the usual starting point is disintegrating total accruals into discretionary accruals and non-discretionary accruals, that is:

$$
\mathrm{TA}_{\mathrm{it}}=\mathrm{DA}_{\mathrm{it}}+\mathrm{NDA}_{\mathrm{it}}
$$

According to modified Jones model, TA $_{\mathrm{it}}$ is computed using Equation (3)

$$
\begin{aligned}
\mathrm{TA}_{\mathrm{it}} / \mathrm{A}_{\mathrm{it}-1}= & \beta_{1}\left(1 / \mathrm{A}_{\mathrm{it}-1}\right)+\beta_{2}\left(\Delta \mathrm{REV}_{\mathrm{it}}-\Delta \mathrm{REC}_{\mathrm{it}} / \mathrm{A}_{\mathrm{it}-1}\right) \\
& +\beta_{3}\left(\mathrm{PPE}_{\mathrm{it}} / \mathrm{A}_{\mathrm{it}-1}\right)+\varepsilon_{\mathrm{it}}
\end{aligned}
$$

where: $\mathrm{A}_{\mathrm{it}-1} \quad=$ total assets lagged by a year

$\triangle \mathrm{REV}_{\mathrm{it}} \quad=$ changes in operating revenue

$\Delta \mathrm{REC}_{\mathrm{it}} \quad=$ changes in net receivables

$\mathrm{PPE}_{\mathrm{it}} \quad=$ gross value for plant, property and equipment

Similarly, $\varepsilon_{\mathrm{it}}=\mathrm{NDA}_{\mathrm{it}}$ is also derived for Equation (4)

$$
\mathrm{NDA}_{\mathrm{it}} / \mathrm{A}_{\mathrm{it}-1}=\beta_{1}\left(1 / \mathrm{A}_{\mathrm{it}-1}\right)+\beta_{2}\left(\Delta \mathrm{REV}_{\mathrm{it}} / \mathrm{A}_{\mathrm{it}-1}\right)+\beta_{3}\left(\mathrm{PPE}_{\mathrm{it}} / \mathrm{A}_{\mathrm{it}-1}\right)+\varepsilon_{\mathrm{it}}
$$

Therefore, deducting Equation (4) from Equation (3) gives discretionary accruals, $\mathrm{DA}_{\mathrm{it}}$ as follows:

$$
\mathrm{DA}_{\mathrm{it}} \quad=\mathrm{TA}_{\mathrm{it}} / \mathrm{A}_{\mathrm{it}-1}-\mathrm{NDA}_{\mathrm{it}} / \mathrm{A}_{\mathrm{it}-1}
$$

However, it is noteworthy that absolute values for discretionary accruals were utilized because either positive or negative, they both represent opportunistic earnings management behavior by management.

\section{Independent Variables}

Table 1 describes proxies under consideration in this study alongside their measurement and sources from previous works. 
Table 1

Description and Measurement of Independent Variables

\begin{tabular}{|c|c|c|c|}
\hline Variables/ Label & Measurement & Predicted Sign & Source(s) \\
\hline Firm size (FZ) & $\begin{array}{l}\text { Big4(1) vs Non- } \\
\text { Big4(0) }\end{array}$ & - & $\begin{array}{l}\text { Almarayeh et al. (2020), } \\
\text { Lopes (2018), Alzoubi } \\
\text { (2016), Al-Mousawi and } \\
\text { Al-Thuneibat (2011). }\end{array}$ \\
\hline Audit tenure (AT) & $\begin{array}{l}\text { Length of auditor- } \\
\text { client relationship }\end{array}$ & + & $\begin{array}{l}\text { Nawaiseh (2016), } \\
\text { Okolie (2014), Zgarni, } \\
\text { et al. (2012), Ebrahim } \\
\text { (2001). }\end{array}$ \\
\hline $\begin{array}{l}\text { Auditor } \\
\text { independence (AI) }\end{array}$ & $\begin{array}{l}\text { Natural log of } \\
\text { audit fees charged } \\
\text { by auditor }\end{array}$ & $-1+$ & $\begin{array}{l}\text { Almarayeh et al. (2020), } \\
\text { Nawaiseh (2016), } \\
\text { Okolie (2014), Wooten } \\
\text { (2003), Craswel et al. } \\
\text { (2002). }\end{array}$ \\
\hline \multicolumn{4}{|l|}{ Control Variables } \\
\hline $\begin{array}{l}\text { Return on Assets } \\
\text { (ROA) }\end{array}$ & $\begin{array}{l}\text { Net income } \\
\text { divided by total } \\
\text { assets }\end{array}$ & - & $\begin{array}{l}\text { Lopes (2018), Alzoubi } \\
\text { (2016), Zgarni et al. } \\
\text { (2012). }\end{array}$ \\
\hline Total Assets (TA) & $\begin{array}{l}\text { Natural log of total } \\
\text { assets }\end{array}$ & - & $\begin{array}{l}\text { Mohammed \& Abibakar } \\
\text { (2018), Lopes (2018), } \\
\text { Alzoubi (2016), Zgarni } \\
\text { et al. (2012). }\end{array}$ \\
\hline
\end{tabular}

\section{Model Specification and Estimation Techniques}

The model for the study is as specified in Equation (6):

$$
\begin{aligned}
& E M_{i t}=\beta_{0}+\beta_{1} F Z_{i t}+\beta_{2} A T_{i t}+\beta_{3} A I_{i t}+\beta_{4} R O A_{i t}+\beta_{5} T A_{i t}+\varepsilon_{i t} \\
& \text { where: } \mathrm{EM}=\text { Earnings Management } \\
& \text { FZ = Audit Firm Size } \\
& \text { AT = Auditor's Tenure } \\
& \text { AI = Auditors' Independence } \\
& \text { ROA = Return on Asset } \\
& \text { TA }=\text { Total Asset } \\
& \varepsilon \quad=\text { Error Term }
\end{aligned}
$$


The panel ordinary least square (OLS) regression is the estimating technique adopted in this study. Initially, the above equation assumes a simplest approach by running a pooled regression. This was later followed by the fixed effects and random effects Models estimation in order to account for the deficiency of oversimplification and overcome the highly restricted assumptions associated with pooled regression.

\section{Results}

The results of the analysis are presented in this section. It is divided into two major sub-divisions namely: descriptive statistics and empirical regression analysis. The descriptive analysis describes basic attributes with the aid of mean, standard deviation, minimum and maximum values. The correlation test was employed to examine relationships among selected variables while the empirical regression analysis revealed the effect of audit quality on earnings management using the commonly used panel regression approach.

\section{Descriptive Statistics}

This section describes the basic statistical features of chosen variables in this study. Table 2 presents the summary of the descriptive statistics, that is, mean, standard deviation, minimum and maximum values for the variables used in this study.

Table 2 reveals that discretionary accruals have a minimum and maximum value of -13.38 and 0.71 , respectively with a mean value of 0.00 and standard deviation at 0.75 . This connotes a negligible presence of accrual earnings management with a consequential skew towards negative, showing the prevalent of income decreasing (negative discretionary accruals) earnings manipulation type among selected non-financial firms; hence reported earnings is associated with greater level of accounting conservatism practices. In comparison, the mean value appears to be consistent with that documented by Okolie (2014) being -0.00 (0\%), which is indicative of a very low level of earning manipulations among quoted non-financial firms, as compared to 0.1492 (15\%) with deposit money banks in Nigeria as revealed by Akintayo and Salman (2018). However, higher values were reported in developing economies of Jordan being -0.415 (42\%) by Nawaiseh (2016) and Saudi Arabia being -0.103 (10\%) by Habbash \& Alghamdi (2016). This is plausible as banks tend to manipulate earnings than non-financial firms. 
Table 2

Summary Statistics of Variables Used

\begin{tabular}{lrrrr}
\hline Variables & Mean & Std. Dev. & \multicolumn{1}{c}{ Min } & Max \\
\hline DA & 0.00 & 0.75 & -13.38 & 0.71 \\
FZ & 0.68 & 0.47 & 0.00 & 1.00 \\
AT & 3.63 & 2.24 & 1.00 & 10.00 \\
AI & 26778.05 & 43703.36 & 1000.00 & 366672.00 \\
ROA & 0.055 & 0.113 & -0.143 & 0.38 \\
TA & 55000000.00 & 212000000.00 & 270036.00 & 3620000000.00 \\
\hline
\end{tabular}

However, FZ, a proxy for Big4/non-Big4, is seen to have an average value of 0.68 with a standard deviation of 0.47 and a minimum and maximum value of 0.00 to 1.00 . By implication, 68 percent of total sample size (20 firms), were audited by Big4 while 32 percent (representing 10 firms) engaged the non-Big4 accounting firms. This is a further affirmation as to the dominance of the Big4 audit firms in Nigeria (Soyemi, 2015; Soyemi, 2020). This is unlike the Tunisian context where 31 percent of total sampled firms engaged the Big4 while 69 percent engaged the non-Big4 firms. The mean and standard deviation value of AT are depicted as 3.63 and 2.24 respectively. Its minimum and maximum value ranges from 1.00 to 10.00 . This indicates that auditors were engaged on an average of approximately four years. This is within the time limit allowed by the corporate governance code in Nigeria. Furthermore, AI, proxied with audit fees, shows a mean value of approximately N27 million with a standard deviation of 43703.36 , minimum and maximum value of N1million and N367 million respectively. In addition, ROA reveals 0.38 as its maximum and -0.143 as its minimum with a standard deviation value of 0.113 and a mean value of 0.055 denoting that most selected firms are less profitable. Finally, TA is revealed to have a minimum value of $\mathrm{N} 270$ million and $\mathrm{N} 3$ trillion as its maximum value with a standard error of 212000000 and mean value of N550 million.

\section{Correlation Analysis}

Table 3 presents the correlation matrix for the selected variables in this study. This is important in examining the level of associations between dependent variable and independent variables on one hand, and identify the multicollinearity tendencies, if any, among independent variables, on the other hand. This is a condition precedent to estimating the model specified for this study using pooled ordinary least square (OLS). 
Table 3

Correlation Matrix amongst Variables Used

\begin{tabular}{lllllll}
\hline & DAC & FZ & AT & AI & ROA & TA \\
\hline DA & 1.000 & & & & & \\
FZ & $0.0942 *$ & 1.0000 & & & & \\
AT & 0.0025 & 0.0071 & 1.0000 & & & \\
AI & 0.0448 & $0.3011 * * *$ & $0.0998 *$ & 1.0000 & & \\
ROA & -0.0054 & -0.0382 & 0.0648 & 0.0231 & 1.0000 & \\
TA & $-0.1638 * *$ & $0.4408 * * *$ & $0.1368 * *$ & $0.5839 * * *$ & 0.0196 & 1.0000 \\
\hline Note: $* * * * *$ and $*$ significance at $1 \%, 5 \%$ and $10 \%$ levels of significance respectively.
\end{tabular}

Generally, the correlations among the variables are weak with few ones that are significant at 1 percent significance level. All the explanatory variables are positively correlated with DA except for the control variables, ROA and TA which are negative. However, though TA is negatively correlated with DA, almost all of its values are significant. The correlation between DA and FZ is seen to be weak and significant at 10 percent level of significance with $p$-value of 0.0874 while the correlation between DA and AT is positive, it is also seen to be weak and insignificant. AI and DA are also seen to exhibit a positive and weak correlation, though insignificant, while ROA represents a negative correlation with DA and is still not significant. However, TA has a negative and weak correlation with DA; it is also seen to be statistically significant at 1 percent with a probability value of 0.0028 . Conversely, other relationships which are revealed to be statistically significant are AI with FZ and AT at 1 percent and 10 percent level of significance while correlations of TA with FZ, AT and AI are at 1 percent, 5 percent and 10 percent levels of significance respectively. All these correlations are seen to be positive and weak, thereby posing no threat of multicollinearity.

\section{The Variance Inflation Factor}

The Variance Inflation Factor (VIF) was piloted to further confirm the absence of multicollinearity. Table 4 shows the values for the test, alongside its inverse.

Judging from the result as shown in Table 4, All VIF are less than 10 so, these indicate that the variables under consideration are not perfect linear combination of each other. 
Table 4

Variance Inflation Factor

\begin{tabular}{lcl}
\hline Variable & VIF & $1 /$ VIF \\
\hline TA & 1.74 & 0.574 \\
AI & 1.52 & 0.656 \\
FZ & 1.25 & 0.798 \\
AT & 1.03 & 0.974 \\
ROA & 1.01 & 0.993 \\
\hline
\end{tabular}

\section{Empirical Analysis: Panel Regression Analysis}

Table 5 depicts the results of the estimated coefficients of audit quality and firm characteristics indicators using pooled (OLS), random effects model (RE) and fixed effects model (FE). In selecting the appropriate model, the Breusch and Pagan Lagrangian multiplier (LM) test was done to compare pooled and random effect model while Hausman test was deployed to choose between random effects and fixed effects model. In this study, it is observed that fixed effects model is appropriate for this study. Specifically, the LM 2.16 ( $\mathrm{p}=0.0708$ ) and Hausman test 286.72 (0.0000) statistics shown in the lower portion of Table 5 show preference for fixed effects model. This confirms the applicability of the fixed effects model for this study.

Interpreting the selected fixed effects model in the fourth column of Table 5, F-statistics values of $57.39(\mathrm{p}=0.000)$ indicate that the selected explanatory variables are jointly and statistically significant in explaining variations in earnings management. Specifically, the value of R-squared, being 0.494, shows that the explanatory variables jointly explain about 49 percent of changes in earnings management, proxied with discretionary accruals. Furthermore, audit tenure exhibits a positive and significant (at $1 \%$ with a p-value of 0.001) influence on discretional accrual, implying that additional one year in auditor tenure will cause discretional accrual to change by five units. Correspondingly, AI which is the variable for auditor's independent, also maintains a positive and significant relationship (at $1 \%$ with a p-value of 0.000) with discretional accrual. Lastly, the result shows that the coefficients of Return on Assets (ROA) and Log of Total Assets (LTASS) have negative coefficients, denoting a negative relationship of the two control variables with discretional accrual, with only TA displaying a negative and significant relationship with DA at $1 \%$ level of significance. 
Table 5

Estimation Results

\begin{tabular}{|c|c|c|c|}
\hline & Pooled & Random & Fixed \\
\hline $\mathrm{FZ}$ & $\begin{array}{l}31.6823 * * * \\
(9.4985)\end{array}$ & $36.0994 * * *(11.1880)$ & 20.4753 (13.4779) \\
\hline AT & $\begin{array}{l}1.0669 \\
(1.7984)\end{array}$ & $\begin{array}{l}1.4343 \\
(1.7749)\end{array}$ & $5.0833 * * *(1.4482)$ \\
\hline $\mathrm{AI}$ & $0.3416 * * *(0.1123)$ & $0.4319(0.1285)^{* * *}$ & $0.5054 * * *(0.1379)$ \\
\hline ROA & $\begin{array}{l}0.0000 \\
(0.0005)\end{array}$ & 0.0000 & $\begin{array}{l}-0.0036 \\
(0.0003)\end{array}$ \\
\hline TA & $-16.1357 * * *(3.0376)$ & $-23.8319 * * *(3.6826)$ & $-104.6592 * * *(6.1801)$ \\
\hline $\mathrm{C}$ & $229.1445 * * *(46.0906)$ & $348.0875 * * *(56.3381)$ & $1663.535 * * *(99.1376)$ \\
\hline $\begin{array}{l}\text { Number of } \\
\text { obs }\end{array}$ & 330 & 330 & 330 \\
\hline R-squared & 0.089 & 0.284 & 0.494 \\
\hline Adj R-squared & 0.0745 & & \\
\hline Wald chi2(5) & & $\begin{array}{l}43.67 \\
(0.0000)\end{array}$ & \\
\hline $\mathrm{F}(\operatorname{Prob}>\mathrm{F})$ & $\begin{array}{l}6.30 \\
(0.0000)\end{array}$ & & $\begin{array}{l}57.39 \\
(0.0000)\end{array}$ \\
\hline LM Test & \multicolumn{2}{|c|}{$\begin{array}{c}2.16 \\
(0.0708)\end{array}$} & \\
\hline
\end{tabular}

Hausman Test

Note: $* * * * *$ and $*$ significance at $1 \%, 5 \%$ and $10 \%$ levels of significance respectively.

\section{Diagnostics Tests}

Table 6 presents Jarque-Bera normality test and White's test for heteroscedasticity as diagnostics for analysis conducted for this study. The Jarque-Bera test statistic is employed to check whether the residual (error term) of the estimated model when discretionary accrual is regressed on audit quality indicators and control variables is normally distributed. As shown in Table 6, the J-B test statistics (1.787) and its associated $p$-value (0.409) are statistically insignificant. These strongly suggest the acceptance of the null hypothesis of normality, thus concluding that the residual of the estimated regression model is normally distributed. Furthermore, White's test approach was adopted for heteroscedasticity test. Again, the test statistics value of 13.764 and the corresponding P-value of 0.101 are statistically insignificant 
within the 1 percent and 10 percent alpha levels. These strongly failed to reject the null hypothesis of homoscedasticity. Therefore, the study concludes that the residual of the estimated regression model has constant variance that is homoscedastic in nature. Alternatively, the study concludes that the residual of the estimated regression model is free from heteroscedasticity problem.

Table 6

Results of Diagnostic Tests

\begin{tabular}{lcc}
\hline Test & $\begin{array}{c}\text { Jarque-Bera } \\
\text { normality test }\end{array}$ & $\begin{array}{c}\text { White's test for } \\
\text { Heteroscedasticity }\end{array}$ \\
\hline Statistic & 1.787 & 13.764 \\
$p$-value & 0.409 & 0.101 \\
\hline
\end{tabular}

\section{Discussion}

While findings from this study are analogous to that of past studies, inconsistencies were noticed as well. Commencing with the coefficient of determination, that is, the adjusted $\mathrm{R}^{2}(49 \%)$ obtained from this study, it mirrors that which was obtained in the studies by Alzoubi (2016) - 45 percent and Nawaiseh (2016) - 48 percent in Jordan and lower (13.4\%) in the case of Okolie (2014) but relatively higher (63\%) for that conducted by Akintayo and Salmon (2018) in the Nigerian banking sector.

Further and turning to individual measures of audit quality in relation to preventing the occurrence of earnings manipulation by management, clientauditor tenure displayed positive and significant association with earning management. This implies that the longer the tenure of external auditors, the greater the incidence of earnings manipulation by mangers without being detected by them. This is expected as familiarity sets in thereby creating threats to audit quality. This result complies with that of Yasser and Soliman (2018), Zgarni, Hlioui and Zehri (2012), but contradicts that of Piot and Janin (2005), Okolie (2014), Nawaiseh (2016), Tyokoso et al. (2017) and Akintayo and Salman (2018). Similarly, findings around auditor independence, especially proxied with audit fees, as used in this study, appear mixed as both positive and negative association are justified and explained appropriately. Here, auditor independent being positive and statistically significant indicates a direct association with earnings management, implying that higher fees, especially from one client, impair auditor independence, hence unable to detect material misstatements, thereby eroding audit quality. 
Simply put, the more dependent external auditors on the clients, the less the audit quality. This is consistent with studies by Jayeola, Agbatoogun and Akinrinlola (2017) but in contrary with Nawaiseh (2016). This is as documented in the study by Habbash and Alghamdi (2016). Surprisingly but expectedly, firm size, measured with Big4/non-Big4 dichotomy, displays positive but insignificant relationship with discretional accrual. This is consistent with other Nigerian studies Okolie, 2014; Akintayo \& Salman, 2018; and Jayeola et al., 2017) and a host of results from developing nations of Jordan (Almarayeh, Aibar-Guzmán, \& Abdullatif, 2020); Tunisia (Zgarni et al., 2012) with real earnings management]; [Chen, Chen, Lobo, \& Wang (2011)] and developed countries of Australia (Molik et al., 2013) during the global financial crisis and France (Piot \& Janin, 2005). On the other hands, it contradicts studies from emerging countries such as Indonesia (Ahmad et al., 2016), Jordan (Alzoubi, 2016) and Tunisia (Zgarni et al., 2012) with accrual earnings management] as well as developed nations of USA (Jordan et al., 2016) and Portugal (Lopes, 2018). In Nigeria, the consistency may also be contextual-related being a country with low investor protection, evolving corporate governance and relatively absence of court cases, that is, low litigation risk against external auditors, thereby tacitly allowing for lower accounting conservatism practices but greater earnings manipulation by management. In addition, this may be connected with the on-going uproar against the perceived impression of equating Big4 professional firms with high quality. This is evidenced in the wave of scandals involving the Big4 across the globe, especially in the US, UK, Germany and India.

That clients' size displayed a negative and significant relationship with earning management connotes that the larger the size of entities, the less managers are allowed to display opportunistic behaviour by deliberately manipulating earnings. Relating this to Nigerian context where ownership structure of quoted non-financial firms are concentrated, it then means that investors (largely institutional) exhibit excellent oversight functions over managers entrusted with firms' resources. No doubt, this is reinforcement to external audit activities towards the detection of material misstatements in the financial statements. This is consistent with studies by Mohammed \& Abibakar (2018), Yasser \& Soliman (2018), Habbash \& Alghamdi (2016) and Lobo \& Zhou (2006). In addition, it is also a tacit support to the proposition by Watts and\& Zimmerman (1986) cited in Piot \& Janin (2005) as to the propensity of management of large firms to engage more in incomedecreasing in order to avoid partisan pressure. However, this finding negate that of Zuo \& Guan (2014) who in addition to others, reported a positive and significant association between the size of the firm and incidence of earnings management in China. 


\section{Conclusion and Recommendations}

This paper seeks to contribute to the on-going debate on the influence of audit quality on constraining managers' opportunistic behaviour in reporting earnings correctly. The findings emanating from this study clearly provide empirical evidence that the audit quality will deter the management's tendencies to stage-manage report earnings. No doubt, the elongated auditor tenure creates the conflict of interest and undue familiarity, thereby culminating in auditor dependent, leading to low auditor quality. This is irrespective of auditor type. It is recommended that policies, guidelines and principles to deter undue auditor term elongation, coupled with auditor independence should be further strengthened by appropriate authorities, as these have the propensities to hinder earnings manipulations by Nigerian firms. There are provisions in the code of conduct for professional members issued by IFAC, and adopted by members of the professional bodies, including the Institute of Chartered Accountants of Nigeria (ICAN). The current practice of audit engagement partner and/ or auditor switch after certain years of continuous engagement should be sustained by relevant authorities and policy makers in order to avoid an erosion of auditor independence, thereby causing a reduction in the audit quality. While this study may have contributed significantly to extant literatures by providing plausible explanations as to audit quality and earnings management in emerging country like Nigeria, there are a few limitations, hence findings therein may be subject to these, which may also be indicative of direction for future researchers. The absence of accrual earnings manipulation among studied Nigerian firms may be a suggestive of tacit diversion to engagement of other earnings management strategies such as real manipulation of actual transactions, as a result of the external auditors' skills to uncover them. This is coupled with the use of signed discretionary accruals rather than absolute earnings management (both income increasing and decreasing discretionary accruals). Further, the twin adoption of a relatively small but adequate sample size (due to the availability of data but comprises highly capitalised quoted firms) and the exclusion of quoted financial firms may also create apparent limitations which future research may address.

\section{Acknowledgement}

This research received no specific grant from any funding agency.

\section{References}

Abbadi, S. S., Hijazi, Q. F., \& Al-Rahahleh, A. S. (2016). Corporate governance quality and earnings management: Evidence from Jordan. Australasian Accounting, Business and Finance Journal, 10(2), 54-75. 
Ahmad, L., Suhara, E., \& Ilyas, Y. (2016). The effect of audit quality on earning management within manufacturing companies listed on Indonesian Stock Exchange. Research Journal of Finance and Accounting, 7(8), 132-138.

Akintayo, J. S., \& Salman, R. T. (2018). Effects of audit quality and corporate governance on earnings management of quoted Deposit Money Banks (DMBs) in Nigeria. International Journal of Economics and Management Engineering, 12(6), 690-696.

Alao, B. B., \& Gbolagade, O. L. (2019). The influence of audit quality on earnings management among listed oil and gas companies in Nigeria. International Journal of Academic and Applied Research, ISSN, 2643-9603

Aliyu, M. D., Musa, A. U., \& Zachariah, P. (2015). Impact of audit quality on earnings management of listed deposit money banks in Nigeria. Journal of Accounting and Financial Management, 1, 30-46.

Almarayeh, T. S., Aibar-Guzmán, B., \& Abdullatif, M. (2020). Does audit quality influence earnings management in emerging markets? Evidence from Jordan. Revista de Contabilidad-Spanish Accounting Review, 23(1), 64-74.

Al-Mousawi, R. J., \& Al-Thuneibat, A. (2011). The effect of audit quality on the earnings management activities. Dirasat: Administrative Sciences, 161(718), 1-32.

Alzoubi, E. S. S. (2016). Audit quality and earnings management: Evidence from Jordan. Journal of Applied Accounting Research, 17, 170-189.

Azibi, J., Azibi, H., \& Tondeur, H. (2017). Institutional activism, auditor's choice and earning management after the Enron collapse: Evidence from France. International Business Research, 10(2), 154-168.

Charoenwong, C., \& Jiraporn, P. (2009). Earnings management to exceed thresholds: Evidence from Singapore and Thailand. Journal of Multinational Financial Management, 19(3), 221-236.

Chen, H., Chen, J. Z., Lobo, G. J., \& Wang, Y. (2011). Effects of audit quality on earnings management and cost of equity capital: Evidence from China. Contemporary Accounting Research, 28(3), 892-925.

Chi, W., Lisic, L. L., \& Pevzner, M. (2011). Is enhanced audit quality associated with greater real earnings management? Accounting Horizons, 25(2), 315-335.

El Guindy, M. N. \& Basuony, M. A. (2018). Audit firm tenure and earnings management: The impact of changing accounting standards in UK firms. The Journal of Developing Areas, 52(4), 167-181.

Habbash, M., \& Alghamdi, S. (2017). Audit quality and earnings management in less developed economies: The case of Saudi Arabia. Journal of Management \& Governance, 21(2), 351-373. 
Hijazi, Q., \& Al-Thuneibat, A. (2015, April). Auditor's opinions and earnings management: Evidence from Jordan. In Proceedings of the third International Conference on Innovation Economy, University of Jordan, Amman, Jordan, 14-15.

Hosseini, M. R., \& Tareq, M. A. (2016). The impact of audit quality and earnings management conceptual. In proceedings of the 13th International Conference on Innovation \& Management, MalaysiaJapan International Institute of Technology (MJIIT), Malaysia Yamaguchi University, Japan 901-906.

International Federation of Accountants (IFAC) (2009). International Standard on Auditing (ISA) No. 240: The auditor's responsibility to consider fraud in an audit of financial statements, the International Auditing and Assurance Standards Board (IAASB).

Jayeola, O., Agbatogun, T., \& Akinrinlola, T. (2017). Audit quality and earnings management among Nigerian listed Deposit Money Banks (DMBs). International Journal of Accounting Research, 5(2), 1-5.

Jordan, C. E., Clark, S. J., \& Hames, C. C. (2010). The impact of audit quality on earnings management to achieve user reference points in EPS. Journal of Applied Business Research (JABR), 26(1).

Knechel, W. R. (2016). Audit quality and regulation. International Journal of Auditing, 20(3), 215-223.

Lobo, G. J., \& Zhou, J. (2006). Did conservatism in financial reporting increase after the Sarbanes Oxley Act? Initial evidence. Accounting horizons, 20(1), 57-73.

Lopes, P. A. (2018). Audit quality and earnings management: Evidence from Portugal. Athens Journal of Business \& Economics, 4(2), 179-192

Miko, N. U., \& Kamardin, H. (2015). Impact of audit committee and audit quality on preventing earnings management in the pre-and postNigerian corporate governance code 2011. Procedia-Social and Behavioral Sciences, 172, 651-657.

Mohammed, L., \& Abibakar, N. (2018). Related party transactions, off balance sheet items and earnings quality of listed deposit money banks in Nigeria. Malaysian Management Journal, 22, 19-34.

Molik, A. T., Mir, M., Mclver, R., \& Bepari, M. K. (2013). Effects of audit quality on earnings management during the global financial crisis: An empirical analysis of Australian companies. In proceedings of 9th Asian Business Research Conference, Cancun, Mexico, 16, 1-19.

Mousawi, J. R., \& Thuneibat, A. (2011). The effect of audit quality on the earnings management activities. Administrative Sciences, 38(2), 614628.

Nawaiseh, M. E. (2016). Impact of external audit quality on earnings management by banking firms: Evidence from Jordan. British Journal of Applied Science and Technology, 12(2) 1-14. 
Okolie, A. O. (2014). Auditor tenure, auditor independence and accrual-based earnings management of quoted companies in Nigeria. European Journal of accounting auditing and Finance Research, 2(2), 63-90.

Piot, C., \& Janin, R. (2005). Audit quality and earnings management in France. International Journal of Auditing, 9(1), 21-44.

Rohaida, B. (2011). The relationship between governance practices, audit quality and earnings management: UK evidence, Durban theses, Durham University. Available at Durham e-theses online: http:// etheses.dur.ac.uk/1382/

Sitanggang, R. P., Karbhari, Y., Matemilola, B. T., \& Ariff, M. (2019), Audit quality and real earnings management: Evidence from the UK manufacturing sector. International Journal of Managerial Finance, 16(2), 165-181. https://doi.org/10.1108/IJMF-03-2018-0095.

Soyemi, K. A. (2015). Determinants of audit fees among Deposit Money Banks (DMBs) in Nigeria. An Unpublished PhD Thesis, Obafemi Awolowo University.

Soyemi, K. A. (2020). Internal corporate governance practices and choice of external auditor in Nigeria: A logistic regression analysis. Binus Business Review, 11(1), 9-16.

Soyemi, K. A., Ashogbon, F. O., \& Asaolu, T. O. (2016). External audit quality and internal audit attributes: Evidence from quoted nonfinancial companies in Nigeria. The VAS Journal, 13, 249-261.

Soyemi, K. A., Olabisi, J., \& Akintoye, I. R. (2017). Determinants of external auditor quality among Quoted Deposit Money Banks (DMBs) in Nigeria. UNIOSUN International Journal of Business Administration, l(2), 83-99.

Tyokoso, G. M., \& Tsegba, I. N. (2015). Audit quality and earnings management of listed oil marketing companies in Nigeria. European Journal of Business and Management, 7(29), 34 -42.

Yasser, S., \& Soliman, M. (2018). The effect of audit quality on earnings management in developing countries: The case of Egypt. International Research Journal of Applied Finance, 9(4), 216-231.

Zgarni, I., Hlioui, K. \& Zehri, F. (2012). Audit quality and earnings management in the Tunisian context. International Journal of Accounting and Financial Reporting, 2(2), 17.

Zuo, L., \& Guan, X. (2014). The association of audit firm size and industry specialization on earnings management: Evidence in China. The Macrotheme Review: A Multidisciplinary Journal of Global Macro Trends, 3(1), 1-21. 


\section{Appendix}

Companies that Participated in the study and their Sectors

\begin{tabular}{|c|c|c|}
\hline $\mathrm{S} / \mathrm{N}$ & COMPANIES & INDUSTRY/SECTOR \\
\hline 1 & Livestock feeds & Agriculture \\
\hline 2 & Okomu & Agriculture \\
\hline 3 & Vitafoam & Conglomerate \\
\hline 4 & National Salt Company & Conglomerate \\
\hline 5 & Dangote Flour Mills & Conglomerate \\
\hline 6 & Dangote Sugar & Conglomerate \\
\hline 7 & Flour Mills & Conglomerate \\
\hline 8 & AG Leventis & Conglomerate \\
\hline 9 & UACN & Conglomerate \\
\hline 10 & Guiness & Consumer Goods \\
\hline 11 & Nigerian Breweries & Consumer Goods \\
\hline 12 & Unilever & Consumer Goods \\
\hline 13 & Neimeth International & Healthcare \\
\hline 14 & Nestle & Healthcare \\
\hline 15 & Glaxosmithkline & Healthcare \\
\hline 16 & Morison & Healthcare \\
\hline 17 & May \& Baker & Healthcare \\
\hline 18 & NCR & ICT \\
\hline 19 & Beta Glass & Industrial Goods \\
\hline 20 & Cutix & Industrial Goods \\
\hline 21 & DN Meyer & Industrial Goods \\
\hline 22 & Berger Paints & Industrial Goods \\
\hline 23 & BOC Gases & Natural Resources \\
\hline 24 & Trans Nationwide Express & Services \\
\hline 25 & Red Star & Services \\
\hline 26 & Chams & Services \\
\hline 27 & Tantalizers & Services \\
\hline 28 & Ikeja Hotel & Services \\
\hline 29 & Studio Press & Services \\
\hline 30 & NAHCO & Services \\
\hline
\end{tabular}

